\title{
Defending human rights in Colombia
}

\author{
by Sara Chandler
}

$\mathrm{L}$ awyers are the custodians of the rule of law, defenders of human rights and the promoters of access to justice. This is most apparent in societies where there have been decades of conflict and where an emerging civil society is struggling to work through systems of transitional justice to reach a future democracy where the minimum requirements of United Nations standards are respected. This was the challenge set for a group of UK lawyers who participated in a fact finding visit to Colombia in late August 2008.

A joint delegation of the Bar, Law Society and ILEX arrived safely in London on September 1, 2008, following a unique "caravana" of 70 international lawyers to Colombia to investigate the situation of human rights lawyers. Forty two delegates went from the UK with a diverse group of counsel, solicitors, trainees and law students, including two members of the judiciary, the President of ILEX, four Law Society Council members, the President of Devon \& Somerset Law Society, a commercial silk, and solicitors from city corporate firms, as well high street legal aid firms. The educators were present from BPP, the College of Law and the University of Westminster.

Our aim in travelling to Colombia was to give support to professional colleagues and to learn for ourselves about the obstacles to their work and the threats they face. We were invited by the Colombian lawyers' organisation ACADEUM (an umbrella organisation for human rights lawyers) as part of their campaign for the right to free exercise of their profession and access to justice: "Sin Abogados no hay Justicia" - ("There is No Justice Without Lawyers").

We came to understand that Colombia is the riskiest place in the world to be a human rights lawyer. Four key themes ran through our visit: the dangers faced by lawyers and other human rights defenders; the impunity afforded by the state to the perpetrators of murder, kidnapping and threats against critics and opponents of the prevailing social order and their legal representatives; the lack of impartial law enforcement and of access to justice; and the importance of international legal norms and international support to the establishment of human rights in Colombia.

We were privileged to hear from so many Colombian lawyers and human rights defenders from a variety of non governmental organisations. The first full day of the "caravana" consisted of a series of plenary sessions where we heard from international and national organisations, including Avocats Sans Frontieres, the Colombian Commission of Jurists, European Union Observatory, and Peace Brigades International. A number of lawyers and victims' organisation addressed the caravan delegates, giving us a broad picture of the situation. We heard first hand of the threats to the independence of the judiciary, to lawyers who defend human rights, the paramilitary activity and the impunity with which paramilitaries act against human rights defenders.

On the second day the full significance of why we were a caravan became clear as we left in seven teams to fly to visits to different regional centres to investigate and hear evidence of the human rights situation. Colombia has been the scene of armed conflict for the last 60 years between, on one side, the state together with paramilitary organisations, (many of which are widely acknowledged to be state sponsored groups) and, on the other side, left wing guerrillas. Para-militaries and guerrillas are both involved in narco-trafficking, extortion and other criminal activity.

\section{JUSTICE AND PEACE PROCESS}

After more than six decades of conflict, Colombia is struggling to emerge from conflict with transition into peace. Four years ago demobilisation of paramilitary organisations started, with an estimate of 19,000 paramilitaries who were offered a process to investigate the truth of extra judicial killings through a justice and peace process. Paramilitaries were offered a special low sentencing regime in return for testimony before special hearings. I was among a group of nine delegates who visited a justice and peace hearing, and saw that the paramilitary being questioned saying he could not remember the incidents about which he was being questioned. The sentencing regime in the Penal Code is maximum 45 years for homicide and maximum 60 years for more than one homicide. In the Justice and Peace hearings the equivalent is five and eight years. Even with this lenient sentencing regime, there is a limited amount of truth being reached. It is difficult when there are two processes going on, and offenders can request transfer to the justice and peace hearings, whether or not they have any intention of contributing to the truth about the assassinations. 
Despite the demobilisation, paramilitary organisations have survived or regrouped, and the threats, attacks and assassinations continue. We met lawyers who showed us leaflets produced by the paramilitary group "Black Eagles" in which they named lawyers referred to as terrorists and who they threatened to kill. The chilling fact was that lawyers on previous lists had been assassinated. Two of our Colombian colleagues in the room with us were on the list. My group met 12 human rights lawyers in Barranquilla, the centre of the northern coastal region, Costa Caribe. Their ranks had been depleted by six assassinations and 10 lawyers who had gone into exile after threats to them and their families, the remaining lawyers were too few to cope with the need for human rights defenders.

While we were in Barranquilla, we met lawyers who defended trades unionists, students, peasants, indigenous people, and refugees forced off their land to make way for palm oil production. Hours before we arrived in Barranquilla we were shocked to hear the news that a lawyer had been shot and killed in the street in Barranquilla by two men on a motorbike on August 24. He was an ex-public defender and had provided legal support to trades unionists who had blown the whistle on their employers for using their ships to smuggle drugs to Belgium. Lawyers do not have the safety of representing their clients without being stigmatised and associated with the crimes of their clients.

The rule of law is having difficulty surviving at all in Colombia. A few hours after one group of delegates visited the court in Cali, the building was blown up and four people were killed in the early hours of August 31. Our delegates had visited the court with the lawyer acting on behalf of the family of a peasant leader who had been assassinated. The case had been listed for the end of an afternoon, on an application by the accused's lawyer for a three month adjournment. Because of strict time limits the case would be thrown out. On seeing the group of international visitors who had trouped in, the judge set a seven day adjournment for the parties to be ready for trial just before a limitation date became effective. However, not only has the court room been blown up, creating the risk that the accused will go free but also court service staff and members of the judiciary are now on strike in Colombia, bringing most proceedings to a standstill.

Tony Talbot, an immigration judge and MHRT President and member of the delegation had a series of meetings in Bogota. He spoke to a number of human rights and labour lawyers for whom threats, exile and fear of assassination are regular hazards of their working lives. All of them appeared to have friends or colleagues who had been killed in the course of duty. He learned that not only defence lawyers but also prosecutors ("fiscales") were faced with threats and intimidation in the course of their duties. He met with a 'fiscal' (prosecutor) with 26 years experience who had found himself in prison after making a decision to release from detention a large number of people arrested in a mass roundup on the basis of inadequate evidence. Although he was eventually released from prison and acquitted of all charges, his career was at an end and he has not worked since then.

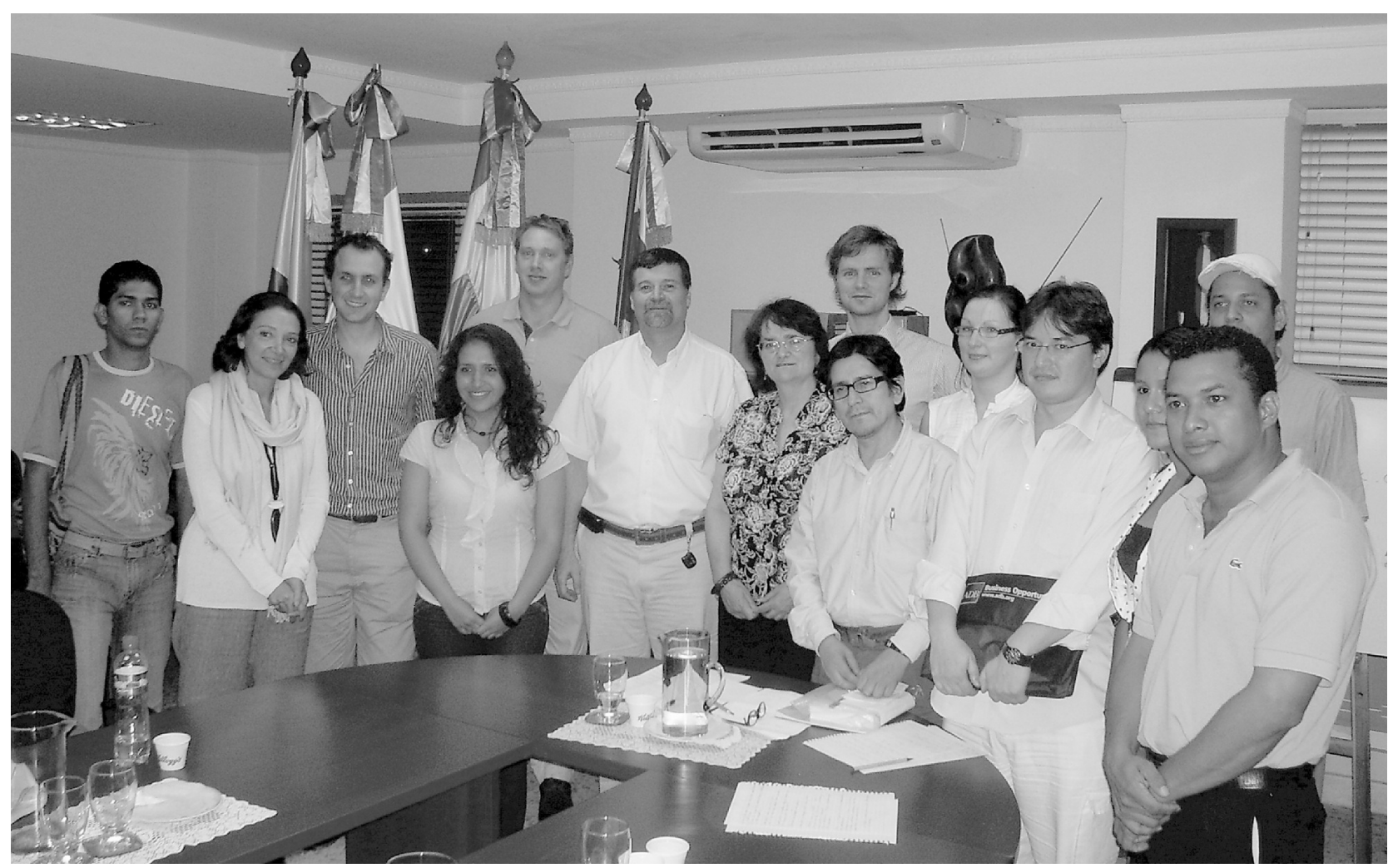

International lawyers meet Appeal Court Judge 


\section{MEETING WITH PROSECUTORS}

The team later met with officials from the central department of the Fiscalia, who told them that threats against "fiscales" happen on a daily basis. They also heard from an official from the ombudsman's office ("defensor del pueblo") who said his telephone was tapped and told of colleagues who had been killed. It appears that despite the framework of a democratic constitution, there is a shadowy world of corruption, intimidation and violence, which infects all aspects of the legal system and makes the profession of lawyer a dangerous occupation in Colombia.

Colombia is the only country in South America which has no independent professional association to represent lawyers. Draft legislation for Congress has been consulted upon, but has not found sufficient support from all sections of the legal profession. Colombian lawyers are organised in a variety of representative bodies, the majority being the alumni associations of the university law faculties, or organisations representing sectional or local interests. The proposal is to create a national organisation, and the topic was raised on several occasions during the visit. A group of UK delegates, commercial lawyers from firms such as Clifford Chance, Herbert Smith, Linklaters and Bircham Dyson Bell, met with Colombian lawyers for a series of meetings and attended the conference of ANDI, the legal services chamber of national business associations of Colombia. Their aim was to assess the support for a national organisation which would include human rights defenders as well as commercial lawyers.

During the last six months, the Law Society and the International Bar Association Human Rights Institute have obtained support from the Law Society Charity for a scoping exercise in Colombia in order to assess the next steps towards the formation of an independent professional representative association for lawyers in Colombia. The establishment of an independent bar association will be an important step in providing protection for human rights defenders.

The UK delegation was the largest of the international delegations, and we met with North and South American and European lawyers, thus creating an informal network. My team, which visited Barranquilla, included representatives from the Paris and Madrid bars, as well as commercial, legal aid and government legal service lawyers. Lawyers of a variety of years of experience worked together, including a partner of one of the largest corporate firms, and a partner of a legal aid firm as well as newly qualified solicitors, trainees and law students. A fair number of barristers worked alongside their solicitor learned friends. On our return the delegation has formed links with the Bar Human Rights Committee, and a recent delegation to Colombia included counsel from the "caravan" with other members of the Bar.

Most of the delegation was self funding and thanks go to some firms who sponsored their delegates. The Law Society Charity supported a number of junior lawyers and others from the City of Westminster \& Holborn Law Society (CWHLS) who could not find funding elsewhere. CWHLS has had a four year history of supporting human rights in Colombia. The generosity of the Law Society Charity made it possible such a large group (of 14 CWHLS members) to participate in the "caravan".

\section{INVESTIGATING LAWYER ASSASSINATIONS}

The aim of the delegation was to learn as much as we could about the human rights situation in Colombia and to offer our support to the human rights lawyers at risk. We were able to do that, not only from the testimonies we received from the many Colombians we met, but also from the international reports which we were given on the situation of lawyers in Colombia over the last 10 years. The delegation achieved some success in the short time that we were there. An important achievement is the agreement by Dr Carlos Franco, the Head of the Colombian Vice President's human rights team, to establish a special investigation team to examine the cases of assassinated lawyers.

Because of the Caravan's concerns about impunity in cases of assassinations of lawyers a meeting was arranged for August 29 with Dr Franco. Peter Burbidge, of Westminster University, led a group who reported to Dr Franco details received from the "Colegiatura de abogados litigantes" in Cali of the deaths of lawyers in that area and handed to Dr Franco the report from the Colegiatura, documenting these deaths. Avocats Sans Frontierres (ASF) have documented 400 lawyer assassinations and had told us of 40 deaths this year in the north of Colombia. A meeting four days earlier with the Attorney General on August 25 had resulted in an assurance that the "Fiscalia" would do its utmost to combat impunity in these cases.

Dr Franco proposed regular meetings with ASF and with the lawyers in Cali to look at the cases they had documented, and see how investigations and prosecutions were progressing. In relation to both these matters he would insist on regular update reports on the progress of cases every two months. He would also keep us informed of the results of these bi-monthly meetings, and give instructions to the Fiscalia in Cali. There would be a special contact number so that HR rights defenders and lawyers could get in touch with the police and the appointment of a liaison officer with the local bar. Dr Franco asserted that impunity is a primary concern of the government. The government had already set up special units to look at trade union cases (they meet with the International Labour Organisation every month). They also had a special unit to look at deaths caused by the armed forces. He would now set up a special unit looking at the progress of cases involving lawyers deaths, with regular meetings with the college of litigation lawyers and ASF.

These meetings would follow up on the progress of investigations, how many trials, how many convictions and 
judgments, the state of proceedings and the other details of each case. He hoped that the unit would have the same success as the unit dedicated to trade unionists. According to the Fiscal General this had already increased convictions by 50 per cent. This important achievement needs constant monitoring.

The Spanish lawyers plan to set up a permanent human rights observatory, reporting on the abuses suffered by human rights defenders and the victims they represent. Neena Acharya, of the College of Law Legal Advice Centre and three College of Law students on the visit have started setting up a project to support students at the National University of Colombia. Neena and her team met students of the National University in Bogota: "The Colombian students were all interested in a future where human rights would be respected in their country and we agreed to build real practical support led by students in colleges and universities in the UK." A group of returned delegates, headed up by Kat Craig from Christian Khan Solicitors, is providing support for two political prisoners.

While there we raised the profile of human rights lawyers in Colombia through television broadcasts, newspaper reports, and radio interviews. Interviews with members of our Cali delegation were broadcast on Colombian national television, and on international websites. This was an important aim of the Colombian lawyers who are marginalised and thus threats to their professional livelihood, and their freedom to work as lawyers, go unnoticed by the general population in Colombia.
We also raised the profile of Colombian human rights defenders through numerous meetings with Government officials, prosecutors and the judiciary, as well as the national Embassies of the delegates attending the Caravana. An ad hoc international network of support has grown up out of the delegates from the different countries. Whenever a human rights defender is at risk the network sends letters to embassies and ministers and alerts the international community to the abuses

An international network now exists, and there may be the possibility of creating more international observatories to scrutinise the situation of human rights defenders. Since the beginning of 2009 two members of the delegation have returned to Colombia to participate in two further investigations, and a further delegation left at the end of April. The Caravana Group of Lawyers has now established working groups on various themes. Anyone interested in finding out more should visit the international section of the Law Society's website (or contact sara.chandler@lawcol.co.uk).

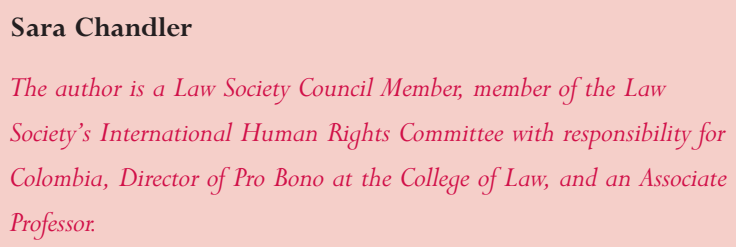

\section{IALS Events}

All events take place at the Institute of Advanced Legal Studies at 18.00 except where otherwise indicated. Lectures and seminars free unless specified. CPD accreditation is provided with many events. For CPD and all other enquiries contact Belinda Crothers, Academic Programmes Manager, IALS, 17 Russell Square, London WC1B 5DR (tel: 0207862 5850; email: IALS.Events@sas.ac.uk). See also our website for further information (http://www.sas.ac.uk/events/list/ials_events).

\section{Monday, 11 May}

\section{SHAMI CHAKRABARTI}

Director of Liberty

Chair: LORD ROGER OF EARLSFERRY

How a lobbying group can affect legislation

Organised in association with the Statute Law Society
Tuesday, 19 May

\section{PROFESSOR CLIVE WALKER}

School of Law, University of Leeds; IALS Visiting Fellow

Prosecuting terrorism

This event is a colloquium and other speakers will be involved.

\section{Wednesday, 27 May}

\section{PROFESSOR JEREMY WALDRON}

New York University Law School; 2008-09 FowlerHamilton Visiting Fellow at Christ Church, Oxford Chair: Mr JUSTICE SALES

Interpretation, textualism and the citation of foreign law

Organised in association with the Statute Law Society 